\title{
O językowej naturze istot nienarodzonych (na tle właściwości walencyjnych implikujących je czasownikowych predykatów)
}

Słowa klucze: semantyka; walencja; życie; dziecko nienarodzone Keywords: semantics; valence; life; unborn child

\section{Wstęp}

Dlaczego zdecydowałem się podjąć ten (pod wieloma względami trudny i, nazwijmy rzecz po imieniu, dość drażliwy) temat? Otóż problem, jaki poruszam, wydaje się nie tylko ważny (i aktualny), ale również (czy może: przede wszystkim) dotąd językowo niezgłębiony. Ponadto, poruszane w tym szkicu zagadnienia korespondują z głównym nurtem moich semantycznych poszukiwań, które ukierunkowuje pragnienie odkrycia systemowo-językowych fundamentów osobowości/podmiotowości; innymi słowy: tego, co kryje w sobie (a może lepiej: ,pod” sobą) tajemniczy (elementarny i uniwersalny) zaimek ktoś. Wszak ostatecznie pytanie o status życia poczętego w języku sprowadza się do kwestii: czy istota nienarodzona jest - w świetle danych językowych - kimś czy czymś (tj. czy przynależy do świata osób czy rzeczy; i jakie można jej, w związku z tym, przypisać w dalszej kolejności atrybuty)? Dyskutowane w tym szkicu wątki zostały już wcześniej dostrzeżone, m.in. przy okazji lingwistyczno-filozoficznych polemik na temat statusu 
osoby, które prowadzili ze sobą: A. Bogusławski (1996: 1-38, 1998: 83-89) oraz J. Jadacki (2003). O ile mi jednak wiadomo, problem istot nienarodzonych (życia poczętego) nie został dotąd (w pracach językoznawczych!) w sposób należyty podjęty i rozwiązany. Tym samym pragnę zatem wypełnić tę dotkliwą lukę, przynajmniej w tej systemowej, mianowicie: ponaddyskursywnej i wspólnoodmianowej, perspektywie ${ }^{1}$.

\section{Spory ideologiczne}

Od pewnego czasu odnoszę wrażenie (i tuszę, że nie jestem w tym odczuciu odosobniony), że w tle głośnego sporu o etyczne i prawne aspekty dopuszczalności przerywania ciąży toczy się cicha dyskusja na temat ontologicznego i antropologicznego statusu życia poczętego. Jako że nie zamierzam (w tej rozprawce) zabierać głosu w konflikcie, którego adwersarze zgłaszaja swój akces do jednego z dwu zantagonizowanych obozów (pro- lub antyaborcyjnego), winien jestem kilka słów wyjaśnień. Po pierwsze, pragnę podkreślić, że szkicując „,portret językowy” życia poczętego, nie tylko odżegnuję się od formułowania jakichkolwiek światopoglądowych deklaracji, ale również zobowiązuję się do tego, iż dołożę wszelkich starań, aby konstruowane przeze mnie hipotezy znajdywały swoje oparcie w materii języka, a nie - w moich osobistych przekonaniach i zapatrywaniach. Po drugie, szanując poglądy i uczucia przedstawicieli każdej ze stron w tym (budzącym emocje, bo dotykającym przecież spraw fundamentalnych) sporze, nie mogę nie zauważyć, że wszelka dyskusja toczy się w języku, który niejako z natury rzeczy jest jeden - dla wszystkich (bez względu na wyznawane racje i poglądy); co więcej, posługują się nim (wszak innym nie dysponują) tak zwolennicy, jak i przeciwnicy aborcji. W związku z tym, nie można ignorować struktury tego, jedynego w swoim rodzaju, wspólnego wszystkim stronom debaty, narzędzia (do wątku tego powrócę w zakończeniu). Tę utrwaloną i zakrzepłą (być może nawet, że już nieco anachroniczną) strukturę języka (czego trop można odnaleźć w walencyjnych właściwościach różnych części mowy) wykorzystam w funkcji poręcznego narzędzia, które umożliwi mi, jak wierzę, dotarcie do

1 W tym miejscu pragnę podziękować Recenzentom za szereg niezwykle trafnych uwag. Bardzo wiele się w ten sposób nauczyłem. I chociaż nie ze wszystkimi uwagami do końca się zgadzam, wszystkie biorę sobie bardzo do serca: obiecuję głęboko przemyśleć i sumiennie rozważyć. 
śladów, jakie rzeczywistość odcisnęła w materii leksykalnej. Co zatem mówi nam o życiu poczętym język - w swoich codziennych i zwykłych, bezpośrednich i dosłownych użyciach?

\section{Terminy naukowe}

W swojej rozprawie podejmuję próbę znalezienia odpowiedzi na pytanie o językowy status życia poczętego. Co zastanawiające, współczesny język polski nie dysponuje (żadną) odrębną jednostką, która mogłaby w stosunku do istoty nienarodzonej pełnić funkcję jej nazwy. Sądzę, że można wręcz zaryzykować twierdzenie, że system języka ujawnia w tym zakresie wyraźną lukę; mianowicie: interesująca mnie wielkość funkcjonuje (w zasadzie) wyłącznie jako porcja treści, jaką implikuje (w pozycjach swoich argumentów) ściśle określona, względnie nieliczna (o czym za chwilę) klasa predykatów. W tekstach współczesnej polszczyzny pojawia się za to kilka - mniej lub bardziej zaangażowanych filozoficznie/ideologicznie i naukowo/medycznieterminów. W swojej pracy posługuję się zamiennie (wstępnie i roboczo) dwoma etykietami: istota nienarodzona oraz życie poczęte ${ }^{2}$. W moim odczuciu, obydwie wywieszki są względnie adekwatne i neutralne, co znaczy, mniej więcej, tyle, iż - z jednej strony - wydają się zasadne i poręczne na wstępnym etapie refleksji, a także - z drugiej strony - nie budzą, mam nadzieję, większych wątpliwości i zastrzeżeń po żadnej ze stron (pobrzmiewającego w tle) aborcyjnego sporu. W szczególności jednakże - i w tę stronę skieruję teraz swoją uwagę - interesują mnie jednostki (wyrażenia) językowe, zwłaszcza czasowniki, przy użyciu których można o istotach nienarodzonych coś (cokolwiek) orzekać (i które - jak się spodziewam - odsłonią prawdziwe ,imię”, jakie noszą w języku istoty nienarodzone) $)^{3}$.

${ }^{2} \mathrm{~W}$ moim osądzie, obie etykietki: istota nienarodzona i życie poczęte - używane wyłącznie jako poręczne skróty (słowa klucze), w sensie technicznym (nie przynależą one wszak do rozważanego uniwersum!) - nie przesądzają w dyskusji ani „na tak”, ani „na nie”, np. z perspektywy biologa zakres orzekania obydwu terminów jest szerszy (maksymalnie szeroki): obejmuje bowiem ogół istot żywych „u progu życia” (a nie jedynie - człowieka).

3 Analiza terminów naukowych oraz opis wiedzy encyklopedycznej (komplementarnych w stosunku do wyrażeń językowych i wiedzy słownikowej; czy może raczej: pozostających z nimi w relacji krzyżowania), jaką posiada na temat istot nienarodzonych oraz życia poczętego przeciętny użytkownik języka, stanowi odrębny (chociaż na pewno interesujący i wart zgłębienia) problem (nie tylko zresztą językoznawczy). 


\section{Wyrażenia językowe}

W swojej pracy planuję przyjrzeć się tym jednostkom języka, które łączy to, iż pojawia się w ich strukturach semantycznych - a ściślej rzecz ujmując: w funkcji któregoś z argumentów tych predykatów - pojęcie istoty nienarodzonej. Interesuje mnie bowiem to, jak mówi się (na poważnie) o życiu poczętym (z intencją mówienia o życiu poczętym), a więc, jakie przypisuje się istotom nienarodzonym (jakie orzeka się o nich) predykaty-orzeczenia (z których będzie można dalej wywnioskować jakieś ich istotne cechy) ${ }^{4}$. Zacznę od tego, że wykroję w materii językowej (w substancji leksykalnej) odpowiedni, choć na tym etapie badań jeszcze daleki od ostatecznego, zbiór spełniających założone warunki jednostek leksykalnych. (W swojej pracy, w kolejnych akapitach i rozdziałach, nawiązuję - pod względem używanych metod opisu - do koncepcji jednostek: A. Bogusławskiego (1976) i M. Grochowskiego (1982), modelu składni wyrażeń predykatywnych S. Karolaka (1984) i zarysu klasyfikacji orzeczeń Z. Zaron (2009)).

Po pierwsze, przedmiot moich analiz będą stanowić wyrażenia językowe (przeciwstawiam je stanowczo terminom naukowym, które traktuję jako ciała obce w łonie języka potocznego, por. inseminować). Po drugie, w centrum moich zainteresowań będą się sytuowały wyrażenia - tak leksemy, jak i frazeologizmy - rodzime i współczesne (w wyraźnej opozycji do obcych i dawnych, por. spędzać płód). Po trzecie, cel moich poszukiwań ogniskować się będzie wokół klasy predykatów otwierających pozycję dla nazw istot nienarodzonych, czyli dookoła zbioru takich jednostek języka, w których podciąg dziecko etykietuje semantyczny argument, a nie - graficzny segment (por. klasy substytucyjne - otwartą o treści 'dziecko' i zamkniętą o formie dziecko, np. zrobić [komuś] dziecko). Ogół orzeczeń, które przywołują nazwy życia poczętego w funkcji swojego semantycznie implikowanego argumentu, rozpada się na dwie podklasy, tj. wyrażenia predykatywne otwierające pozycje, z jednej strony: „tylko”, a z drugiej strony: „nie tylko” (np. dziecko poruszyto się $w$ tonie matki) dla nazw istot nienarodzonych. Obiekt moich

4 W tej pracy szczególną wagę przywiązuję do relacji, jakie wiążą język ze światem; W szczególności interesują mnie możliwości (granice) odnoszenia pewnego zbioru predykatów do określonego typu bytów (temu zadaniu są podporządkowane zabiegi analityczne, jakim poddaje konkretne czasowniki i ich właściwości kompletujące). 
szczególnych zainteresowań będą stanowiły w pierwszym rzędzie te czasownikowe jednostki, którym nieodłącznie towarzyszy porcja treści, jaką wyrażają terminy: istota nienarodzona lub życie poczęte.

Poniżej przedstawiam listę jednostek leksykalnych, a ściślej predykatów czasownikowych, które odpowiadają przyjętym (w poprzednim akapicie) kryteriom. Interesujące mnie jednostki łączę w klasy (synsety) na podstawie ich wspólnych (przystających) cech semantycznych:

1. kategoria: czynność (operacja): 'poczęcie':

1.1. argument $_{1}=$ rola 'dziecko': [ktoś: 'dziecko'] poczęto się (kiedyś/ gdzieś)

1.2. argument $_{1}=$ rola 'matka' $\mathrm{i} / \mathrm{lub}$ 'ojciec':

1.2.1. [ktoś: 'matka' (i/lub 'ojciec')] poczat ([kogoś: 'dziecko'])

1.2.2. [ktoś: 'ojciec' (i 'matka'))] spłodzit [kogoś: 'dziecko']

1.2.3. [ktoś: 'matka'] zaszła (w ciqżę) (z [kimś: 'ojciec']/ z [kimś: 'dziecko'/)

1.2.4. [ktoś: 'matka'] wpadła (z [kimś: 'ojciec'])

2. kategoria: stan: 'ciąża':

2.1. argument $_{1}=$ rola 'dziecko': [ktoś: dziecko] (jest) $w$ drodze

2.2. argument $_{1}=$ rola 'matka' (i 'ojciec'):

2.2.1. [ktoś: 'matka'] jest w ciaży z [kimś: 'dziecko']/z [kimś: 'ojciec']

2.2.2. [ktoś: 'matka'] jest w [którymś] miesiqcu ciaży

2.2.3. [ktoś: 'matka' (i/lub 'ojciec')] będzie mieć [kogoś: 'dziecko']

2.2.4. [ktoś: 'matka' (i 'ojciec')] spodziewa sięloczekuje [kogoś: 'dziecko']

2.2.5. [ktoś: 'matka'] nosi w sobie/pod sercem [kogoś: 'dziecko']

2.2.6. [ktoś: 'matka'] jest w poważnym/odmiennym/blogosławionym stanie

2.2.7. [ktoś: 'matka'] jest ciężarna

2.2.8. [ktoś: 'matka'] jest przy nadziei

3. kategoria: proces (zdarzenie):

3.1. 'poród':

3.1.1. $\operatorname{argument}_{1}=$ rola 'dziecko':

3.1.1.1. [ktoś: 'dziecko'] urodziło się [kiedyś/gdzieś] 
3.1.1.2. [ktoś: 'dziecko’] przyszło na świat [kiedyś/gdzieś']

3.1.2. argument $_{1}=$ rola 'matka':

3.1.2.1. [ktoś: 'matka'] urodziła [kogoś: 'dziecko']

3.1.2.2. [ktoś: 'matka'] wydała na świat [kogoś: 'dziecko']

3.1.2.3. [ktoś: 'matka'] donosiła ciażę/[kogoś: 'dziecko']

3.2. 'śmierć':

3.2.1. naturalna: $\operatorname{argument}_{1}=$ rola 'matka':

3.2.1.1. [ktoś: 'matka'] poroniła ([kogoś: 'dziecko'])

3.2.1.2. [ktoś: 'matka'] straciła [kogoś: 'dziecko']

3.2.2. nienaturalna: (uwaga: kategoria: czynność (operacja))

3.2.2.1. argument $_{1}=$ rola 'inna (w tym: 'matka')':

3.2.2.1.1. [ktoś] usunat [komuś: 'kobiecie'] [kogoś: 'dziecko']/ciaże

3.2.2.1.2. [ktoś] przerwat ciąze

Postać wielu spośród kilkunastu przywołanych wcześniej jednostek może budzić uzasadnione wątpliwości ${ }^{5}$. Rekonstruuję zatem możliwe kształty niektórych z nich, przytaczając w funkcji argumentów skonstruowane na potrzeby analizy przykłady i kontrprzykłady:

(1) Pamiętnego dnia Adam i Ewa poczęli swoje dziecko.

(2) Po wyjeździe z kraju Ewa poczęła swoje pierwsze dziecko.

(3) Adam pochwalit się kolegom, że niedawno począt swojego pierworodnego.

(4) Adam i Ewa spłodzili kilkoro dzieci.

(5) Adam spłodzit syna/córkę.

(6) *Ewa spłodziła syna/córkę.

(7) Adam i Ewa będq mieć/spodziewajq się dziecko/dziecka.

(8) Ewa będzie mieć/spodziewa się dziecko/dziecka.

(9) ?Adam będzie mieć/spodziewa się dziecko/dziecka.

a. *Spodziewam się dziecka (syna/córki). 'ojciec: o sobie'

5 Warto zauważyć, że wiele spośród przywoływanych czasowników dopuszcza swoje użycie wyłącznie w czasie przeszłym, por. Ewa zaszła w ciażę z Aniq 'córka', wobec: *Ewa jest $w$ ciaży $z$ Ania 'córka'. i Ewa jest $w$ ciaży z Adamem 'ojcem'. Nie zmienia to jednak faktu, że istoty nienarodzone, o których się rzeczone predykaty na serio (chociaż jedynie w funkcji odległej przeszłości) orzeka, otrzymują kwalifikację personalną. 
b. ?Będę mieć dziecko (syna/córkę). 'ojciec: o sobie'

(10) Ewa jest w ciaży/zaszła w ciażę z Adamem. 'ojciec'

a. Kiedy zaszłam w ciażę z Adamem, miałam dwadzieścia lat. 'matka: o sobie i o ojcu'

b. Jestem $w$ ciaży $z$ Adamem, a nie $-z$ Janem. 'matka: o sobie i o ojcu'

(11) Ewa jest w ciaży/zaszła w ciażę z Jasiem. 'dziecko'

a. Kiedy zaszłam w ciaże z Jasiem, miałam dwadzieścia lat. 'matka: o sobie i o dziecku'

b. Kiedy byłam w ciaży z Jasiem, miałam dwadzieścia lat. 'matka: o sobie i o dziecku'

(12) *Ewa zaszła w ciażeljest w ciaży z Adamem i Jasiem. 'matka: o ojcu i o synu'

Kluczowy problem stanowi w moim szkicu kwalifikacja podciągu dziecko (jako argumentu bądź segmentu) w ciągach, które reprezentują interesujące mnie - ze względu na założony (w tytule i we wstępie) nadrzędny cel - jednostki języka. Innymi słowy: chodzi o to, czy podciąg ów ma w tych jednostkach ten sam status, co w wyrażeniach: wylać dziecko z kqpiela (dziecko jako segment) i dziecko rozwija się prawidłowo (dziecko jako argument). Inaczej mówiąc: czy podciąg dziecko stanowi element klasy substytucyjnej zamkniętej czy otwartej, jedno- czy też wieloelementowej? Rzecz jasna. począć, nosić pod sercem i urodzić można tylko dziecko, nic innego:

(13) Dziecko przyszło na świat o trzy tygodnie za wcześnie, watty chłopczyk umieszczony zostat natychmiast w inkubatorze.

(14) Maja dwoje dzieci, a trzecie jest w drodze.

(15) W ciagu dwunastu lat swego pożycia spłodzili czworo dzieci.

(16) Wiesz chyba, jak kobiety boja się rozwiazania, jakie bywaja nerwowe, gdy oczekuja dziecka.

(17) Z obliczeń wynika, że dziecko poczęło się w maju.

Nie znaczy to jednak, że w interesujących mnie połączeniach podciąg dziecko etykietuje klasę substytucyjną zamkniętą jednoelementową. Wręcz przeciwnie: twierdzę, że w dyskutowanych pozycjach możliwa jest substytucja segmentu dziecko przez klasę leksemów o treści 'dziecko' (zob. syn - 
córka, chłopczyk-dziewczynka, Jaś-Matgosia). Moje przypuszczenia i domysły znajdują swoje potwierdzenie w licznych przykładach użycia, których obficie dostarczają tak słowniki językowe, jak i korpusy tekstowe:

(18) Matka poczęla mnie w pierwszym dniu wojny.

(19) Nie donosiła syna, urodziła w siódmym miesiacu.

(20) Po dwóch latach malżeństwa żona powiła mu upragnionego syna.

(21) Spłodzić córkę.

(22) Toż mnie akurat $w$ czterdziestym piatym matka na świat wydała.

(23) Urodzity się im trojaczki.

(24) W cztery lata później przychodzi na świat moja siostra.

Kontynuując podjęty wątek, sygnalizuję, że - wbrew rozpowszechnionej leksykograficznej praktyce (ISJP i USJP) - nie godzę się ani na to, by rozróżniać treści: 'dziecko nienarodzone' i 'dziecko narodzone', ani na to, by sens 'dziecko nienarodzone’ włączać do szerszej kategorii ‘dziecko ze względu na wiek'. Po pierwsze, można sobie wyobrazić akceptowalne przykłady, w których potomstwo (obecne, przeszłe i przyszłe) jednych rodziców sytuuje się obok siebie, zgodnie, na tym samym poziomie, zaspokajając wymagania walencyjne powiązanych ze sobą w zdaniach czasowników ${ }^{6}$ :

(25) Ewa ma obecnie dwoje dzieci (wcześniej jedno zmarło), trzecie $w$ drodze, a wraz z mężem myśla już o czwartym.

(26) Pierwsze dziecko Adama i Ewy poszło już do szkoły, drugie - do przedszkola, a trzecie przyjdzie na świat za miesiac.

Po drugie, uważam, że zachodzi pilna - szczególnie w kontekście dyskutowanych tu kwestii - potrzeba odróżnienia (od siebie) dwóch jednostek: dziecko 'ze względu na wiek' oraz dziecko [czyjeś] 'ze względu na pokrewieństwo' - z jednoczesną kwalifikacją istot nienarodzonych do tej drugiej kategorii. Śmiem twierdzić, że przemawiają za tymi hipotezami pewne argumenty:

6 Niewykluczone, że sytuacja, jaką opisuję, stanowi - w ujęciu diachronicznym rezultat procesu polegającego na rozciągnięciu nazwy istoty narodzonej (faza finalna) na nienarodzoną (faza przed-finalna). 
(27) *Jaś, który się jeszcze nie urodzit, jest jeszcze dzieckiem. 'wiek'

(28) Jaś, który się jeszcze nie urodził, jest (nienarodzonym) dzieckiem Adama i Ewy. 'pokrewieństwo'

(29) Jaś, który ma kilka lat, jest dzieckiem Adama i Ewy. 'pokrewieństwo'

(30) *Jaś ma kilka lat i jest jeszcze dzieckiem Adama i Ewy. 'pokrewieństwo \& wiek'

(31) Jaś ma kilka lat i jest jeszcze dzieckiem. 'wiek'

(32) Jan, który ma kilkadziesiat lat, jest dzieckiem Adama i Ewy. 'pokrewieństwo'

(33) *Jan ma kilkadziesiat lat i jest jeszcze dzieckiem Adama i Ewy. 'pokrewieństwo \& wiek'

(34) *Jan ma kilkadziesiat lat i jest jeszcze dzieckiem. 'wiek'

Podsumowując tę część mojego wywodu, mogę stwierdzić, że (ogólny) przegląd wymagań walencyjnych pewnej nieprzygodnej klasy predykatów (ściśle: czasowników implikujących w roli jednego ze swoich argumentów porcję sensu 'życie poczęte') pozwala ujawnić prawdziwe ,imię”, jakie język przewiduje dla ludzkich istot nienarodzonych; ,imię" to (w zasadzie, rzecz jasna, nie ,imię własne”, a „nazwa ogólna”) brzmi: dziecko (swoich rodziców).

\section{Pola leksykalne}

Otrzymany podzbiór predykatów-orzeczeń (wyrażeń języka - rodzimych i współczesnych, otwierających miejsce walencyjne tylko dla nazw istot poczętych), można „podsumować” pod względem ich istotniejszych właściwości: syntaktycznych, semantycznych i pragmatycznych. Z czysto syntaktycznego punktu widzenia zajmujące mnie w tej pracy predykaty implikują, na odrębnych piętrach struktur predykatowo-argumentowych, trzy pozycje argumentowe, którym przyporządkowuję funkcje (role): 'ojciec', 'matka' i 'dziecko'. W perspektywie semantycznej predykaty te desygnują: czynność, stan i proces, por. 'poczęcie', 'ciążę' i 'poród' (jak również ‘śmierć': naturalną lub nienaturalną). W ujęciu pragmatycznym predykaty te można natomiast odnosić do istot nienarodzonych w taki sposób, że mówi się o nich, przyjmując jedną $\mathrm{z}$ dwóch perspektyw (osadzonych w momencie albo przed, albo po 
narodzinach), np. dziecko przyjdzie na świat bądź dziecko przyszło na świat (wątek ów wymaga jednak pogłębionych studiów).

Jednostki słownikowe, które przywołałem i wyodrębniłem, tworzą wspólnie swego rodzaju mikropole semantyczne. Wyszczególnione przeze mnie czasownikowe predykaty zawierają w swoich reprezentacjach semantycznych, na różnych ich piętrach i w różnych swoich układach, identyczne składniki treści, np. 'czynność poczęcia', 'stan ciąży', 'proces porodu lub śmierci' (te trzy komponenty uobecniają się w strukturach pojęciowych większości spośród kilkunastu dyskutowanych wyrażeń). Role zworników w projektowanym mikropolu pełnią semantycznie najogólniejsze (i pragmatycznie neutralne) jednostki, które reprezentują (swoje) obszerniejsze synsety:

1. [ktoś I $_{1,2}$ poczat [kogośn

2. [ktośf jest w ciaży (z [kimś, $\left.\left.\dot{s}_{2,3}\right]\right)$

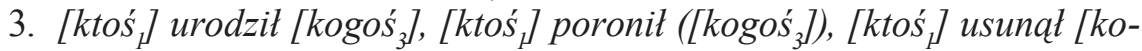
goś $\left._{3}\right]$.

Co istotne, znaczenia tych jednostek pozostają do siebie w określonych relacjach; mianowicie czasowniki w rodzaju [ktoś ${ }_{1,2}$ p poczat [kogośs] implikują (pod asercją), natomiast czasowniki typu [ktośf] urodzit [kogośs], [ktoś,] poronit ([kogoś,]) i [ktoś,] usunat [kogoś,] presuponują (pod asercją i pod negacją), treść (sens), jaką wyrażają czasowniki pokroju [ktośs jest w ciaży $\left(z\left[\right.\right.$ kims $\left.\left._{2,3}\right]\right)$. Nie bez znaczenia pozostaje fakt, iż zręby pojęciowe wszystkich, powiązanych ze sobą gęstą siatką relacji, wyrażeń organizują się wokół jednej wspólnej kategorii 'dziecko'. Pokrewieństwo semantyczne w analizowanej klasie jednostek ujawniają eksplikacje ich treści. Sytuacje, jakie opisują wyszczególnione predykaty, przedstawiają się (w kategoriach prostych jednostek) następująco: 'rodzice dziecka, czyli ojciec i matka, mężczyzna i kobieta, posiadają zdolność przekazywania życia: robią coś takiego (czynność), że staje się coś takiego (proces), że dziecko zaczyna żyć w taki sposób, że znajduje się w łonie matki, będąc przy tym jakby jej częścią (stan); następnie z matką staje się coś takiego (proces), że jej dziecko przestaje żyć w taki sposób, że znajduje się w łonie swej matki, będąc jakby jej częścią, a zaczyna żyć w taki sposób, że znajduje się poza jej łonem, przestając być jakby jej częścią'. W tym ujęciu, istota nienarodzona jest 'dzieckiem swoich rodziców, 
które póki co żyje w taki sposób, że znajduje się w łonie matki, będąc jakby jej częścią'.

\section{Hipotezy semantyczne}

Na podstawie zgromadzonego materiału językowego: zarówno pozytywnego (teksty), jak i negatywnego (testy), w kolejnych ustępach sformułuję szereg hipotez (kandydatów do statusu zdań analitycznych) na temat istot nienarodzonych. Żywię przy tym nadzieję, że przynajmniej niektóre z tych prób pozwolą uchwycić niezbywalne i nieprzygodne atrybuty życia poczętego.

Po pierwsze, stawiam hipotezę, jedną z najważniejszych w całej pracy, w myśl której życie poczęte nie jest po prostu czymś. Predykaty, które otwierają miejsca walencyjne dla nazw istot nienarodzonych, nie akceptują bowiem w przewidywanych dla nich pozycjach (w rozmaitych układach i konfiguracjach) klas jednostek (w rodzaju): zygota, zarodek, płód ${ }^{7}$, które (przecież) zgodnie podpadają pod - substytuujący świat rzeczy - zaimek coś (zob. materiał negatywny). W pozycjach argumentowych, które implikują odpowiednie czasowniki, zupełnie swobodnie i naturalnie realizuje się za to - kluczowy dla tez wyłożonych w tym artykule - leksem dziecko (zob. materiał pozytywny):

materiał negatywny (testy)

(35) *Adam i Ewa poczęli (swoja/swój) zygotę/zarodek/płód.

(36) *Zygota/zarodek/płód poczęła/począt się kilka dni/tygodni/miesięcy temu.

(37) *Kiedy Ewa była w ciaży z (swoja/swoim) zygota/zarodkiem/płodem, nie skarżyła się na brak apetytu.

(38) *Ewa spodziewa się (swoja/swojego) zygoty/zarodka/płodu.

(39) *Ewa nosi w sobie/w tonie/ pod sercem (swoja/swój) zygotę/zarodek/płód.

7 Nie sposób nie zgodzić się z twierdzeniem, że elementy: zygota, zarodek i płód posiadają swoją jednoznaczną kwalifikację jako terminy naukowe. Na prawach wyjątku włączam je do analizowanego materiału negatywnego. Sądzę bowiem, że zderzenie wyrażeń i terminów (zwłaszcza w kontekście podejmowanej w tej pracy tematyki) szczególnie dobitnie pokazuje różnice zachodzące między światami: osób i rzeczy. 
(40) *Zygota/zarodek/płód (Ewy) urodzi się/przyjdzie na świat za kilka dni/tygodni/miesięcy.

(41) *Ewa poroniła (swoja/swój) zygotę/zarodek/płód.

(42) *Ewa straciła (swoja/swój) zygotę/zarodek/płód.

(43) *Ewa, zanim powiła czworaczki, nosiła pod sercem kolejno: cztery zygoty, cztery zarodki, cztery płody i czworo dzieci.

(44) *Ewa spodziewa się dziecka (synka/córeczki), które póki co nie jest jeszcze dzieckiem tylko zygota/zarodkiem/płodem.

(45) *Kiedy dziecko przyjdzie na świat, to będzie dzieckiem, teraz jest jedynie zygota/zarodkiem/płodem.

(46) *Zanim maty Adaś przyszedt na świat, nie był dzieckiem, tylko zygota/zarodkiem/płodem.

(47) *Maty Adaś urodzit się przedwcześnie; urodzit się zatem jako zygota/zarodek/płód.

(48) *Skoro Ewa urodziła swojego synka Adasia przedwcześnie, to znaczy, że urodziła zygotę/zarodek/płód, a nie-dziecko.

materiał pozytywny (teksty)

(49) Dziecko, które poczęło się w momencie przestępstwa, nie jest temu winne, a jest karane.

(50) Dziś w końcu pocznie się nasze dziecko.

(51) Jeśli to dziecko jest spłodzone przeze mnie, to powinno być do mnie podobne.

(52) Po wojnie urodziło się wiele dzieci, które poczęty się w wyniku gwattu.

(53) Pomyślałam sobie wtedy, że on jest taki odpowiedzialny, że on po prostu mnie nie zostawi z ta ciaża, że nie popchnie mnie ku aborcji, że nie będzie miat do mnie pretensji, gdyby poczęło się dziecko, tylko weźmie odpowiedzialność za konsekwencje wspólżycia, że po prostu stanie na wysokości zadania.

(54) Upragnione dziecko poczęło się w terminie, jaki wcześniej ustaliliśmy.

(55) W ciagu dwunastu lat swego pożycia spłodzili czworo dzieci.

(56) Z obliczeń wynika, że dziecko poczęło się w maju.

(57) Z prostych obliczeń wynika, że właśnie wtedy poczęło się dziecko.

(58) Zabicie dziecka $w$ fazie rozwoju prenatalnego jest nieporównywalnie większym złem niz wychowywanie go $w$ trudnych warunkach materialnych, niż ewentualna choroba dziecka, niż trudności $w$ za- 
akceptowaniu i pokochaniu dziecka, gdy poczęło się ono wbrew woli matki.

(59) Zdarza się często, że kobiety stosujace metody naturalne popetnity jakiś bład, np. źle odczytały wykres, nie wzięty pod uwagę ważnych danych $i$ w wyniku tego przeoczenia lub niewiedzy poczęło się dziecko.

(60) Bytam w ciaży z drugim dzieckiem.

(61) Byto nas już troje dzieci, a mama nosiła pod sercem czwarte.

(62) Jestem zdziwiona, że macie małe dziecko, drugie $w$ drodze, a Ania tyle pracuje.

(63) Ona zaś nosiła w łonie dziecię własnego ojca.

(64) Pragne, by kobieta, która nosi pod sercem moje dziecko, zechciała mi towarzyszyć przez reszte naszych dni i byśmy nasze nienarodzone dziecko mogli wychować na kochajacego Boga człowieka.

(65) To ona będzie nosita w sobie dziecko.

(66) Wiesz chyba, jak kobiety boja się rozwiqzania, jakie bywaja nerwowe, gdy oczekuja dziecka.

(67) Wstyd dziedziczce korony nosić pod sercem nieślubne dziecko.

(68) Kiedy dowiedziat się, że żona jest w ciqży, kazat jej usunqć dziecko.

(69) Lekarz zdecydowanie radził usunqć dziecko.

(70) Rok wcześniej poroniła ich wspólne dziecko.

Co więcej, w świetle danych językowych sytuacja przedstawia się tak, że istota nienarodzona pozostaje dzieckiem (swoich rodziców) przez cały czas: od momentu poczęcia, gdy przebywa w łonie matki, a nawet wówczas, kiedy zostanie wydana na świat martwa:

(71) *Ewa poroniła, ale nieprawda, że straciła dziecko.

(72) *Ewa mimo komplikacji donosita ciażę, ale nie donosita dziecka.

Kolejne przykłady pokazują dobitnie, chociaż zapewne, w moim odczuciu, nieco drastycznie, iż dziecko nie stanowi jakiejś (w sensie: jednej z wielu pod jakimś względem równorzędnych) części matki, lecz podlega osobnej kwalifikacji - jako odrębny (choć na obecnym etapie życia niesamodzielny), obdarzony własną (inherentną) osobowością/ podmiotowością, byt: 
(73) Ewę $w$ minionym roku dotknęty trzy tragedie: najpierw stracita męża, potem rodziców, a na koniec - swoje nienarodzone dziecko.

(74) *Ewę w minionym roku spotkały trzy nieszczęścia: najpierw stracita prace, potem oszczędności, a na dodatek - swoje nienarodzone dziecko.

(75) *Ewa poddała się kilku zabiegom: najpierw usunęła nadłamany zab, potem nadmiar tluszczu, a na koniec - swoje nienarodzone dziecko.

(76) *Przecież Ewa usunęta (tylko) ciażę, a nie - dziecko.

Po drugie, formułuję przypuszczenie, zgodnie z którym istota nienarodzona jest kimś, czyli - mówiąc nieco bardziej technicznie - pozwala się zastępować w wielu, a niewykluczone, że i we wszystkich, kontekstach zaimkiem osobowym $k t^{\prime} s^{8}$. Jakie argumenty przemawiające za tą tezą mogę przedłożyć? Otóż predykaty wprowadzające nazwy istot nienarodzonych w pozycji implikowanego argumentu tolerują w swoim bezpośrednim sąsiedztwie leksemy typu: synek i córeczka, chłopiec i dziewczynka, Jaś i Małgosia, które każde z osobna lub wszystkie razem - poddają się substytucji przez zaimek osobowy ktoś, ale również, co (w moim przekonaniu) decydujące, dopuszczają (zawsze) możliwość zamiany na rzeczownik dziecko (z oczywistych względów w tej pozycji wykluczone są podstawienia w rodzaju: noworodek i niemowlę, czyli nazwy dzieci 'ze względu na ich wiek'):

materiał negatywny (testy)

(77) Adam i Ewa poczęli swojego synka (Jasia)/swoja córeczkę (Matgosię) kilka tygodni/miesięcy temu.

(78) Nasz synek (Jaś)/nasza córeczka (Małgosia) począt się/poczęła się kilka tygodni/miesięcy temu.

(79) Kiedy Ewa byta w ciaży z Jasiem/Małgosia, nie skarżyła się na brak apetytu.

(80) Ewa spodziewa się chtopczyka/dziewczynki.

(81) Ewa nosi w sobie/w tonie/pod sercem swojego nienarodzonego syn$\mathrm{ka} /$ swoja nienarodzonq córeczkę.

${ }^{8}$ Wypowiedzi typu Czy już im się coś urodziło? interpretuję jako twory językowe, których nie można umieścić w ramie asertorycznej (dixit), jaką wyznacza czasownik: [ktoś] powiedział [komuś] o [kimśsczymś], że p (oraz jego wyraziste hiponimy, np. [ktoś] zdradzit [komuś], że p). Szerzej na ten temat: Bogusławski 2009. 
(82) Nasz synek (Jaś)/nasza córeczka (Małgosia) urodzi się/przyjdzie na świat za kilka dni/tygodni/miesięcy.

materiał pozytywny (teksty)

(83) Anioł w zębach przynosi wiadomość o tym, że ich potomek pocznie się, kiedy Joachim i Anna pocatuja się pod Ztota Brama.

(84) W takich okolicznościach poczqt się Tezeusz, syn śmiertelnego Ajgeusa i boskiego Posejdona.

(85) W tym wypadku oznaczało to również, że Ronnie nie począ się $w$ wyniku przypadkowego romansu.

(86) Zostat dygnitarzem w Polskich Kolejach Państwowych, ale wcześniej, na obozie skautów nad Dniestrem, zadzierzgną sięego zwiqzek z panna Pogorzelska i tam począt się Kamil.

(87) „Bolesne tajemnice sztuki zostanq rozproszone, oto pojawit się Orion, który śpiewa wewnatrz mnie - ze swymi błękitnymi ptakami i złotymi motylami - cierpię z powodu nieznanej, odległej muzyki" - tymi słowami matka Messiaena, Cécile Sauvage, opisała uczucie, którego doznawała, noszac pod sercem małego Oliviera.

(88) Hagar nie znała granic w przechwatkach, że nosi w tonie syna Abrama, i poczynała sobie coraz zuchwalej.

(89) Jak byłam w ciaży z trzeciq córka, myślałam, że będzie chłopczyk.

(90) Już w jednym z wcześniejszych wierszy, piszac o aborcji, która byta zabiegiem często wykonywanym w Rzymie, żartowat, że gdyby Wenus noszqca w tonie Eneasza dopuściła się przerwania ciaży, nie bytoby dziś cezarów (Cezara i Augusta).

(91) Mieszcze się $w$ wieczorowa sukienke, którq obstalowałam siedem i pót roku temu. Jakja odbierałam, to już byłam w ciaży z Szymkiem i ani razu jej na sobie nie miałam, bo to sukienka-rękawiczka.

(92) Na ścianach dużo grafiki i olejny portret pani Barbary z okresu, gdy byta $w$ ciaży z Zuziq.

(93) Prawie siedem lat temu, kiedy bytam w ciqży z Marysia, wzięłam w telewizji dtugi urlop.

(94) Wiele badań dotyczyło tego, czy została zhańbiona w namiocie przez Holofernesa, zanim mu odcięła głowe, czy też nie. Wedtug Biblii nie, ale u Hebbla została zhańbiona i prawdopodobnie nosi $w$ tonie dziecko Holofernesa. 
(95) Marianne Faithfull poroniła dziecko Micka Jaggera kilka godzin po tym, jak Yoko Ono poronita dziecko Johna Lennona.

(96) Proszę o modlitwe o dar zdrowego potomstwa dla nas, niestety trzy miesiace temu poroniłam naszego ukochanego Syneczka.

Po trzecie, śmiem twierdzić, że (przynajmniej w dziedzinie języka) istota nienarodzona jest - od samego początku - obdarzona życiem (i niczym pod tym względem nie ustępuje istotom narodzonym), por. przykłady: (97) (100). Ponadto, dysponuje pewną porcją wiedzy (pewnie bardziej proceduralnej niż deklaratywnej) oraz przejawia pewną dozę aktywności (co wyczuć może matka (lub ojciec), a zarejestrować lekarz); innymi słowy: (już) coś wie i (już) coś robi ${ }^{9}$, por. przykłady (odpowiednio): (103) - (104) oraz $(101)-(102)$.

(97) Dziecko w tonie matki rozwija się prawidłowo.

(98) Matka nosi w sobie zdrowe/chore dziecko.

(99) Dziecko we wnętrzu matki obumarło.

(100) Ewa urodziła martwe dziecko., wobec: *Adam i Ewa poczęli martwe dziecko.

(101) Dziecko w tonie matki porusza się i przemieszcza., wobec: *Dziecko w tonie matki porusza się i przemieszcza - czy tego chce, czy nie.

(102) Matka czuje, jak dziecko w jej brzuchu kopie., wobec: *Matka czuje, jak dziecko w jej brzuchu nieumyślnie kopie.

(103) Dziecko w szóstym miesiacu ciaży nie tylko styszy, ale również odróżnia od siebie dochodzqce z zewnatrz dźwięki., wobec: *Dziecko w szóstym miesiacu ciaży odróżnia od siebie dochodzace z zewnqtrz dźwięki, ale nieprawda, że wie, że jedne z tych dźwięków sq inne niż drugie.

(104) Dziecko żyjace $w$ brzuszku swojej mamy czuje, $w$ jakim położeniu jest mu wygodnie, a w jakim - nie., wobec: *Dziecko żyjace $w$ brzuszku swojej mamy czuje, w jakim położeniu jest mu wygodnie, ale nieprawda, że wie, w jakim położeniu jest mu wygodnie.

9 Naturalnie, zagadnienie to wymaga głębszego namysłu i szczegółowych studiów. Sądzę jednak, że zarysowana w artykule droga poszukiwań jest obiecująca. 
Własności te ujawniają się szczególnie wyraźnie w tych przykładach użycia, które występują w ramach typu: Rodzice dowiedzieli się od lekarza, że... i Badanie ultrasonografem wykazało, że...:

(105) Położna poinformowata matkę, że jej dziecko owinęło się pępowina.

(106) Rodzice dowiedzieli się od lekarza, że dziecko przed porodem samo ustawia się w odpowiedniej pozycji.

(107) Na ekranie ultrasonografu matka mogła zobaczyć, jak jej dziecko zaciska piqstki i stópki, a nawet jak ssie paluszek.

(108) Dzięki nowoczesnej technice rodzice moga obserwować, jak ich nienarodzone dziecko porusza raczkami i nóżkami.

Rzecz jasna, nasza wiedza na temat tego, co wie i co robi dziecko w łonie swojej matki, wciąż jest jeszcze znikoma; niemniej (z roku na rok) coraz więcej dowiadujemy się o jego ruchowej aktywności i poznawczych zdolnościach.

Po czwarte, istota nienarodzona może stać się wirtualnym adresatem czyichś wypowiedzi, ale także odbiorca, beneficjentem lub malaficjentem, pewnych czynności (co istotne, obie role semantyczno-syntaktyczne angażują tylko i wyłącznie te istoty, które podpadają pod kategorię 'osoby') ${ }^{10}$ :

(109) Adam i Ewa czule przemawiaja do swojego nienarodzonego dziecka., wobec: *Adam i Ewa czule przemawiaja do swoich mebli i ścian.

(110) Doktor zaaplikowat dziecku w tonie matki silne leki.

(111) Lekarze poddali nienarodzone dziecko skomplikowanej operacji.

Po piąte wreszcie, z czego nie wszyscy od razu zdają sobie sprawę, nienarodzone dziecko jest zawczasu obdarzone osobowością i podmiotowością;

10 Argument, jaki przedkładam, zyska - w moim mniemaniu - na sile, jeśli zestawi się (ze sobą) przykłady: Ewa przemawiała czule do swojego nienarodzonego dziecka. (lub Ewa przemawiała czule do swojego psa.) oraz Ewa przemawiała czule do swoich mebli. W moim odczuciu, ostatni przykład, w opozycji do pierwszego (a na pewno do drugiego), to wypowiedź, której bohater, robiąc to, co robi, nie zakłada, że adresat jego wypowiedzi (meble) go słyszy i, co istotne, słucha (przynajmniej w jakimś najogólniejszym sensie, np. rozumienia uczuć i emocji). 
mianowicie: w sposób nieprzenośny zostaje mu nadane imię i najzupełniej poważnie otrzymuje (na mocy ustaw) pewne prawa ${ }^{11}$ :

(112) *Kilka lat temu (gdy) Ewa była w ciaży z Jasiem, który (jeszcze wtedy) nie byt Jasiem...

(113) Kilka lat temu (gdy) Ewa była w ciaży z Jasiem, który (jeszcze wtedy) nie byt ,Jasiem” ...'nie nadano mu jeszcze imienia Jan'

(114) Dziecko od chwili poczęcia pozostaje pod ochrona prawa., wobec: Dziecko od chwili poczęcia nie pozostaje pod ochrona prawa.

(115) Adam od razu uznat swoje dopiero co poczęte dziecko.

W kilku ostatnich akapitach próbowałem wydobyć z żywiołu mowy, utrwalone w systemie językowym, atrybuty nienarodzonych dzieci. Rzecz jasna, daleki jestem od tego, by uznać, że zadanie, jakiego się podjąłem, zostało w pełnym zakresie rozwiązane. Niemniej: zauważyłem problem i zarysowałem drogę, jaką można by w przyszłości podążać, ale także dostarczyłem garści przykładów, które warto - jak wierzę - poddać pod dyskusję.

\section{Zakończenie}

Niniejsza próba wpisuje się w cykl publikacji, jakie - przez ostatnie parę lat - poświęciłem problemowi, którego istotę najwierniej oddają pytania W rodzaju: kim jest ktoś i kto jest kimś? W prezentowanym studium przedłożyłem i przedyskutowałem kilka argumentów językowych (nie: filozoficznych i teologicznych lub naukowych i medycznych), które przemawiają, moim zdaniem, na rzecz określonych tez. W swoich wywodach odwoływałem się do systemu języka - jako ostatecznej instancji: arbitra i autorytetu. Wierzę bowiem, iż to właśnie język potoczny, odporny na ideologiczne inwazje i wtręty, przemijające mody i fascynacje, gromadzi w sobie (i przechowuje) mądrość pokoleń, wiernie służąc pewnej wspólnocie pomyśleń, która

11 W sytuacji, o której tutaj mowa, nie jest istotny aktualny stan prawny, ale raczej sama możliwość orzekania (w języku potocznym) o tym, czy istocie nienarodzonej (dziecku) jakiekolwiek prawa są zagwarantowane, czy nie (w stosunku do rzeczy/ przedmiotów tego rodzaju problem w ogóle nie powstaje). 
ożywia od wewnątrz posługującą się nim społeczność (w tym zjawisku dopatruję się również swoistej metafizycznej konieczności) ${ }^{12}$.

Nie od dzisiaj wiadomo, że język, w którym na co dzień i od lat spontanicznie dzielimy się (sobą i światem) z innymi, zobowiązuje ontologicznie - w tym tego słowa sensie, że obliguje swoich użytkowników do akceptacji istnienia tych bytów, które - jako stałe - są podstawialne pod zmienne kwantyfikowane egzystencjalnie; mam tutaj na myśli stałe jako restrykcje, które język nakłada na realizacje pozycji argumentowych (w tym kontekście przywołuje się zwykle takie wielkości jak: syntagmatyczne pola i substytucyjne klasy, selekcyjne cechy i tematyczne role), które tworzą presupozycyjną warstwę wypowiedzi, w ramach której dochodzi do głosu - zapośredniczona przez wiedzę - rzeczywistość. To, co mam na myśli, najlepiej oddają tezy, jakie w swoim słynnym traktacie sformułował L. Wittgenstein (1997): teza 4.03: Zdanie powiadamia nas o pewnej sytuacji, a zatem jego zwiazek $z$ niq musi być istotny.; teza 4.0621: Zdania , p" $i$, , p" maja przeciwstawny sens, ale odpowiada im ta sama rzeczywistość. W tym duchu warto (czy wręcz: należy) interpretować przedstawione w tej pracy argumenty i rozstrzygnięcia.

\section{Bibliografia}

BogusŁawski A., 1976, O zasadach rejestracji jednostek języka, Poradnik Językowy, z. 8, s. 356-364.

BogusŁawski A., 1996, Świętość jakości życia?, Przeglad Humanistyczny 40/2, s. 1-38. BogusŁawski A., 1997, Do świata przez język, Przeglad Humanistyczny 2, s. 103-129. Bogustawski A., 1998, O „pożytkach karmienia człowieka piersią”, Prace Filologiczne 43, s. 83-89.

12 Portret świata, utrwalony w języku, nosi, co zrozumiałe, znamiona anachroniczne. Czyż jednak nie jest tak, że język, z natury swojej konserwatywny, jest na tyle elastyczny, że stanowi swego rodzaju pomost między (mniej i bardziej) odległymi w czasie interpretacjami świata (umożliwiając zarazem swoim użytkownikom orientację w dynamicznie zmieniającej się rzeczywistości)? Innymi słowy: język nie może nie przystawać do rzeczywistości (w jej najogólniejszych zarysach), bo w ten sposób, rozmijając się z nią, uniemożliwiałby swoim użytkownikom komunikowanie się i, niniejszym, sam by się unicestwił. 
BogusŁawski A., 2002, Światopogląd i wiedza (glosa do pewnej dyskusji), Przeglad Humanistyczny 46, 2(371), s. 1-30.

BogusŁawski A., 2004, Rezygnacja i nadzieja filozofów, Przeglad Humanistyczny 383 , s. 1-26.

BogusŁawski A., 2009, Myśli o gwiazdce i regule, Warszawa: Wydawnictwo BEL Studio Sp. z o.o.

Grochowski M., 1982, Zarys leksykologii i leksykografii. Zagadnienia synchroniczne, Toruń: Wydawnictwo UMK.

ISJP: BАŃко M. (red.), 2000, Inny słownik języka polskiego, t. 1-2, Warszawa: Wydawnictwo Naukowe PWN.

JADACKI J. J., 2003, Aksjologia i semiotyka, Warszawa: Wydawnictwo Naukowe Semper.

Karolak S., 1984, Składnia wyrażeń predykatywnych, w: Z. Topolińska (red.), Gramatyka wspótczesnego języka polskiego. Składnia, Warszawa, s. 11-211: Wydawnictwo Naukowe PWN.

Mıodunka W., 1989, Podstawy leksykologii i leksykografii, Warszawa: Wydawnictwo Naukowe PWN.

NKJP: Narodowy Korpus Języka Polskiego, [online:] http://nkjp.pl.

NowaK T., 2013, Od przesłanki do konkluzji. Polskie czasowniki rozumowania, Katowice: Wydawnictwo Uniwersytetu Śląskiego.

Spaemann R., 2001, Osoby. O różnicy między czymś a kimś, Warszawa: Oficyna Naukowa.

USJP: DuBISz S. (red.), 2003, Uniwersalny stownik języka polskiego, t. 1-6. Warszawa: Wydawnictwo Naukowe PWN.

Wittgenstein L., 1997, Tractatus logico-philosophicus, Warszawa: Wydawnictwo Naukowe PWN.

Zaron Z., 2009, Problemy sktadni funkcjonalnej, Warszawa: Wydawnictwo BEL Studio.

\section{"Sprowadzać dzieci na świat", i.e. about the linguistic nature of unborn beings \\ (against the background of valence properties and the verbal predicates that imply them)}

( su m mary)

The term used in the title has, so far, not been the subject of a more extensive linguistic reflection. The author of the paper aims at providing a description of lexical units implying the argument 'unborn being (child)' with respect to their structure and meaning. The method of analysis is based on proposing hypotheses in the form of analytical implications and subjecting them to falsification by bringing them down to contradiction. The content of the paper focuses on issues relating to 
the reconstruction of the form of lexical units (verbs). In a close reference to the content of the analysed terms, the discussion considers also the following notions: 'żyć', 'wiedzieć', 'robić' and many others. The author tries to prove that those components belong to the semantic structure of the examined phrases with the term child (unborn). 
